\title{
Systematic significance of cypsela morphology in Lessingianthus (Vernonieae, Asteraceae)
}

\author{
María B. Angulo ${ }^{\mathrm{A}, \mathrm{B}}$, María M. Sosa ${ }^{\mathrm{A}}$ and Massimiliano Dematteis ${ }^{\mathrm{A}}$ \\ A Instituto de Botánica del Nordeste (UNNE-CONICET), Casilla de Correo 209, W3400CBL, Corrientes, Argentina. \\ ${ }^{\mathrm{B} C}$ Corresponding author. Email: angulobetiana@gmail.com
}

\begin{abstract}
The taxonomic significance of cypsela features of South American species of Lessingianthus (Vernonieae, Asteraceae) is analysed for the first time and discussed in relation to other genera of the tribe Vernonieae. The morphology of the cypselae of 112 species of the genus were analysed using stereo-, light and scanning electron microscopy (SEM) to evaluate the infrageneric relationships and their reliability as taxonomic markers at a generic level. Characters such as cypsela pubescence, carpopodium structure, crystals and idioblasts on the fruit wall were examined. We established three types of cypsela on the basis of the presence or absence, and type of trichomes. Carpopodium is present in all species of the genus. Crystals are very variable in shape and size, with prismatic (rectangular and hexagonal) and styloid shapes. Idioblasts are present in all of the species, except for two. Cypsela features of Lessingianthus are often widespread in other related genera of Vernonieae. Therefore, these characters are not good taxonomic markers at the genus level, but they are valuable within genera to differentiate related species from one another.
\end{abstract}

Additional keywords: Lepidaploinae, taxonomy.

Received 16 May 2015, accepted 7 August 2015, published online 13 November 2015

\section{Introduction}

Micromorphological features are a potentially important source of information for classification of the family Asteraceae, being especially useful for the characterisation and classification of tribes and genera (Funk et al. 2009). These microcharacters, in combination with other additional characters (type of pollen grains, chromosome number and inflorescence type), were used to classify the tribe Vernonieae. Initially, a subtribal delimitation within Vernonieae was very difficult because most species of tribe were placed in the large genus Vernonia ( 1000 species). This genus was traditionally defined by the absence of characters present in other Vernonieae genera. In addition, the tribe has a large number of monotypic genera with unusual and distinctive morphological characteristics; therefore, the relationship among those genera and with Vernonia was poorly understood. Robinson's (1999) classification changed the circumscription of Vernonia sens. lat., and the genus is currently limited to a small group of 22 taxa from eastern North America, with the other species being in new genera. Lessingianthus H.Rob., one of these new genera, arises from the combination of morphological and micromorphological characters.

At present, Lessingianthus comprises $\sim 133$ species (Angulo and Dematteis 2014) distributed in South America, including Brazil, Bolivia, Paraguay, Argentina, Uruguay, Venezuela, Colombia and Peru (Robinson 2007). Within the tribe, Lessingianthus is generally considered to be most closely related to Chrysolaena H.Rob. and Lepidaploa (Cass.) DC. (Robinson
1999) and molecular studies have supported these relationships (Keeley et al. 2007). Lessingianthus differs from these genera by a combination of characters, such as 'type B' pollen grains, base chromosome number $x=16$, and several micromorphological features, such as non-glandular anther apical appendage, absence of basal stylar node (rarely present), and cubic crystals on the fruit wall (Robinson 1999; Angulo and Dematteis 2010, 2012a, 2014). Recently, Angulo and Dematteis (2014) studied in detail the floral microcharacters (corolla pubescence, shape and size of anther apical appendage, style base) of Lessingianthus species and demonstrated their usefulness to differentiate related species. However, some features are not diagnostic at generic level because some states of these characters, considered 'typical' of Lessingianthus, are also shared with closely related genera such as Chrysolaena and Lepidaploa. Therefore, the search for new diagnostic characters to help clarify the relationships between these genera is necessary.

In Asteraceae, one of approaches that has shown satisfactory results for taxonomy is the analysis of cypsela morphology (Spjut 1994; Roque and Funk 2013; Zhang et al. 2013). The use of cypsela micromorphological characters has proved to be very rewarding for the systematic evaluation of several tribes of Asteraceae, including Anthemideae, Gnaphalieae, Inuleae, Senecioneae, Plucheae and Mutisieae (Abid and Qaiser 2009; Abid and Ali 2010; Abid and Alam 2011; Roque and Funk 2013; Zhang et al. 2013). In Vernonieae, cypsela features vary with the group. For example, only the subtribe Sipolisiinae has cypsela 
walls containing phytomelanin, a characteristic that is absent in other subtribes (Funk et al. 2009). The presence or absence and shape of crystals on the cypsela wall were useful to separate related genera, such as Vernonanthura H.Rob. and Lepidaploa (Funk et al.2009). The persistence of the pappus is also important at a generic level within the subtribes, such as within the tribe Lychnophorinae, where the genus Lychnophora Mart. has a deciduous pappus, whereas Minasia H.Rob. has a persistent pappus. The carpopodium is the scar of the abscission zone on the fruit base, and this is another diagnostic character used at different taxonomic levels, showing differences in the size and shape of wall cells (Funk et al. 2009). Studies at the infrageneric level are scarce; however, fruit morphology has been used in taxonomic keys to differentiate related species (Angulo and Dematteis 2012b; Bunwong et al. 2014; Lander and Hurter 2013). Despite the high number of Lessingianthus species, only one study on the morphology and anatomy of the cypselae was conducted (Martins and Oliveira 2007). These authors compared the fruit morphology and anatomy of L. brevifolius (Less.) H.Rob. and Chrysolaena obovata (Less.) Dematt. (sub nom. C. herbacea (Vell.) H.Rob.) and demonstrated the significance of these features to differentiate related taxa. However, there is still no detailed report available on cypsela micromorphology for Lessingianthus. In the present paper, the fruits of almost all the species of the genus were analysed in a taxonomic context. Our results will contribute to the characterisation of the species, establishing the value of fruit characters as diagnostic of Lessingianthus. In addition, these data are also discussed in relation to the information available on the closely related genera Chrysolaena and Lepidaploa.

\section{Materials and methods}

Cypsela morphology of a total of 112 species was studied with stereo-, light and scanning electron microscopy (SEM). At least five different cypselae per specimen were examined. In total, three specimens per species were analysed depending on material availability. Mature cypselae were collected from plants in the wild or from herbarium specimens (i.e. voucher specimens) from the herbaria ALCB, BR, CESJ, CTES, ESA, G, LP, MBM, P, R, $\mathrm{RB}, \mathrm{SPF}, \mathrm{SI}$ and UB (herbarium abbreviations are according to Index Herbariorum, see http://sweetgum.nybg.org/ih, accessed 20 April 2015). Species and specimen information is listed in Appendix 1, 'Specimens analysed', where the taxa are arranged alphabetically (Table 1).

For observation of cypsela microcharacters, the fruit was softened in distilled water for $5 \mathrm{~min}$, and cleared in sodium hypochlorite: water (1:1) until the samples became transparent. Transparent samples were washed in running water and dissected under a stereomicroscope and then mounted in Hoyer's solution (Anderson 1954; King and Robinson 1970). Samples were examined and photographed using Zeiss Axioplan microscope (Carl Zeiss, Jena, Germany) with digital camera Canon Power Shot A 640 (Tokyo, Japan).

For the anatomical studies, fruit samples were dehydrated following the methodology by Gonzalez and Cristóbal (1997), and were subsequently infiltrated in paraffin (Johansen 1940). Transverse and longitudinal sections were cut into $10-15-\mu \mathrm{m}$ sections with a rotary microtome and mounted on glass slides.
Sections were stained with a safranin-astra blue combination (Luque et al. 1996) and photographed using a Leica DM LB2 light microscope (Leica Microsystems, Wetzlar, Germany) including polarised light.

For histochemical analyses, living material was handsectioned under a stereomicroscope. Cellular content was tested histochemically using Sudan IV for lipids, Lugol's reagent for starch grains, Ruthenium red for pectinaceous materials, and cresyl blue for mucilages. Sections were observed and photographed using light microscope.

The chemical identity of the crystals was tested by the acid treatment described by Zarlavsky (2014). Fruits were softened in distilled water for $5 \mathrm{~min}$ and dissected under a stereomicroscope, and a few drops of $2 \%$ hydrochloric acid were added.

The different types of crystals were measured, considering length and diameter. One hundred crystals for preparations and each crystal type were measured from 10 randomly selected regions.

For observation of cypsela surface sculpturing, mature fruits were first dehydrated and immersed in $\mathrm{CO}_{2}$ for critical-point drying before sputter-coating with gold-palladium. Coated samples were examined and photographed using a JEOL 5800 LV scanning electron microscope (JEOL Ltd, Tokyo, Japan).

The term cypsela was used for Lessingianthus fruits on the basis of the terminology suggested by Marzinek et al. (2008). Terminology of trichome morphology follows Metcalfe and Chalk (1979), whereas terminology of remaining cypsela characters follows Robinson (1999), and Roque et al. (2009).

The Infostat software package (Di Rienzo et al. 2013) was used for comparative analysis of cypsela characters of Lessingianthus species. A principal coordinate analysis ( $\mathrm{PCoA})$ using Manhattan distance metric was performed to evaluate the variability of fruit characters among examined species. A data matrix of 112 operational taxonomic units (OTUs) and four qualitative variables was constructed (data matrix is available on request from the senior author). The different character states for each of them are given in Table 2 .

\section{Results}

Cypselae of Lessingianthus vary between cylindrical and obconical, and some species show an intermediate shape designated here as cylindrical-obconical (see Table 1). However, fruit length (without pappus) is highly variable, ranging from 1.5 to $9 \mathrm{~mm}$. Lessingianthus exiguus has the smallest fruit length $(1.5-1.8 \mathrm{~mm})$, whereas L. monocephalus has the largest value $(8-9 \mathrm{~mm})$. All the species have more or less conspicuous longitudinal ribs. The pappus is whitish or yellowish, biseriate, with an outer series of short paleaceous setae $(0.5-2 \mathrm{~mm})$, fimbriate, lanceolate (Fig. 1A) to linear, and an inner series with long cylindrical bristles (4.5-12 $\mathrm{mm})$.

\section{Trichomes}

Cypsela surface in most of the analysed species shows trichomes, although some taxa have glabrous fruits (Table 1). The trichomes are multicellular, glandular or non-glandular. On the basis of the presence of trichomes as well as the observed types, we classify three fruit types, as defined below. 


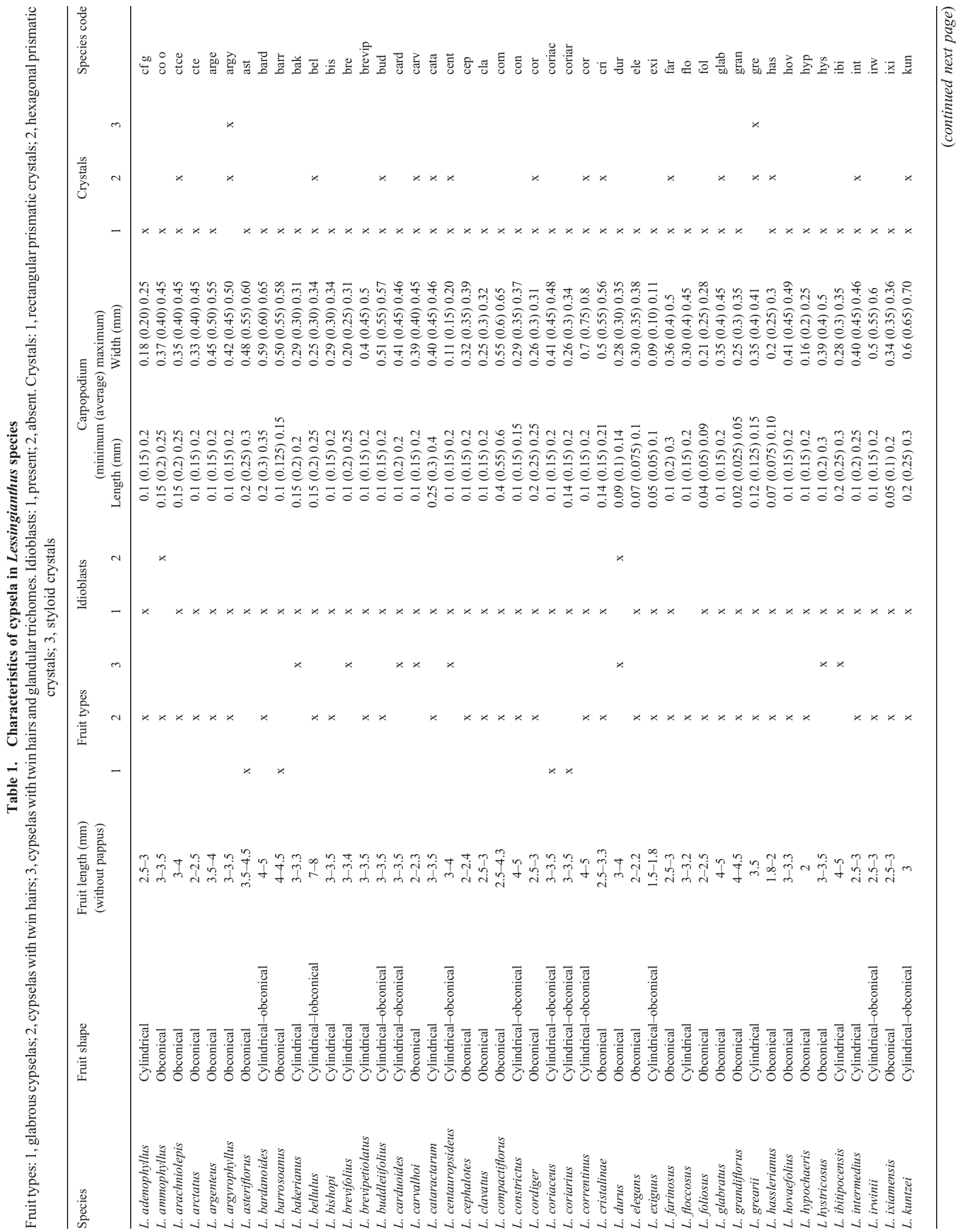




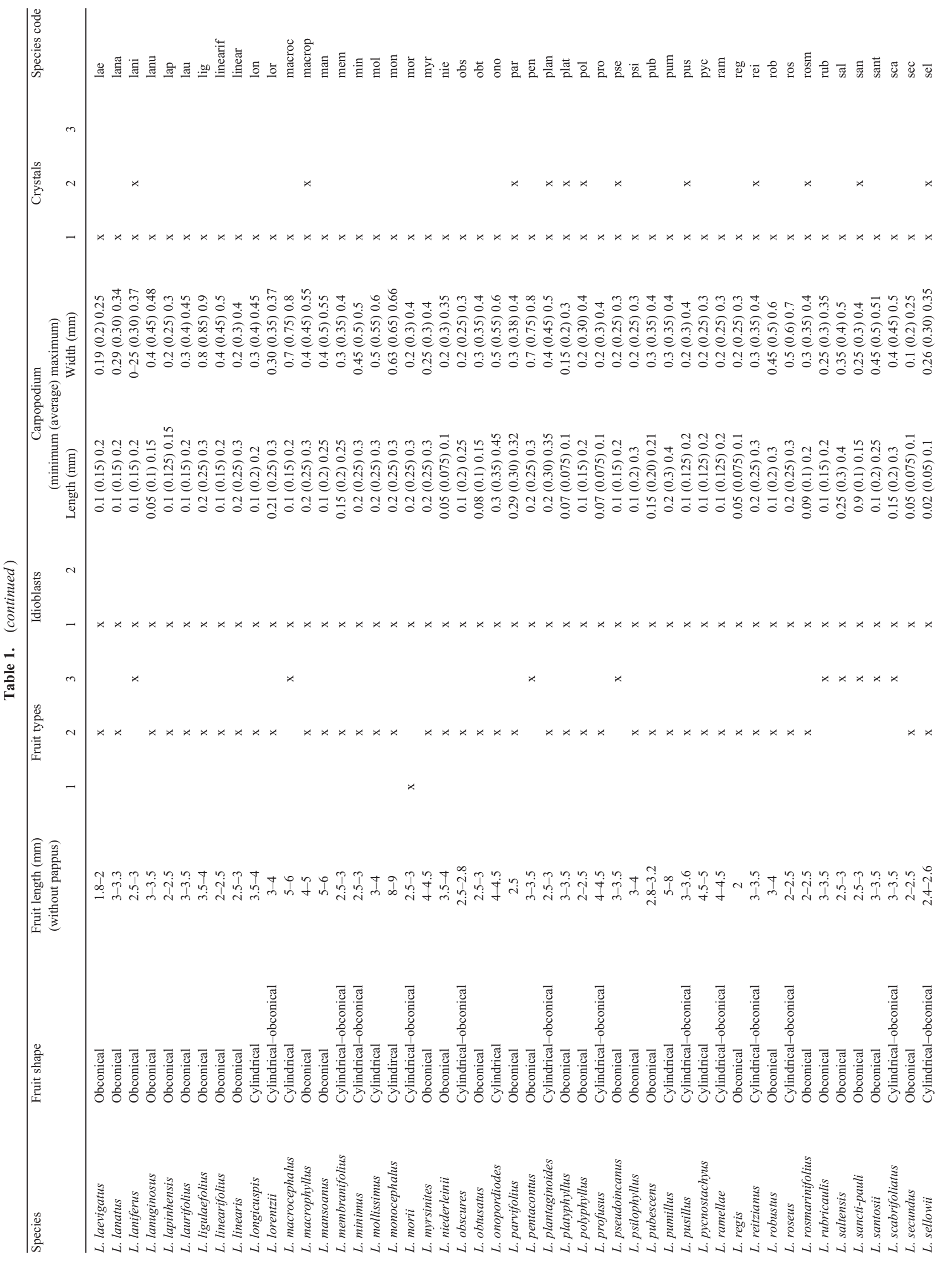




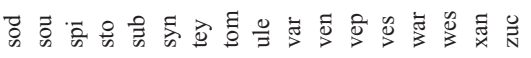

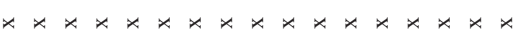

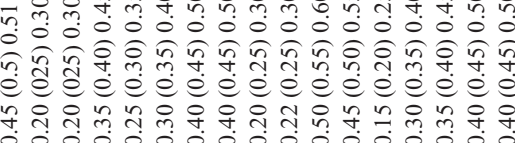

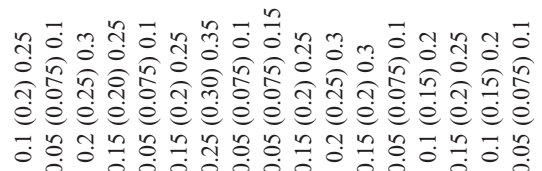
$\star$

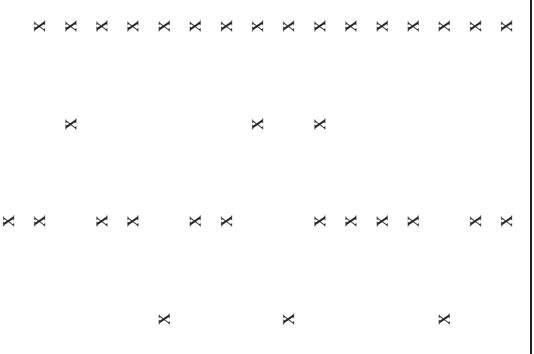

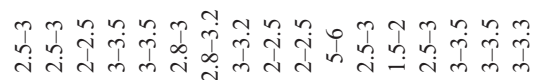

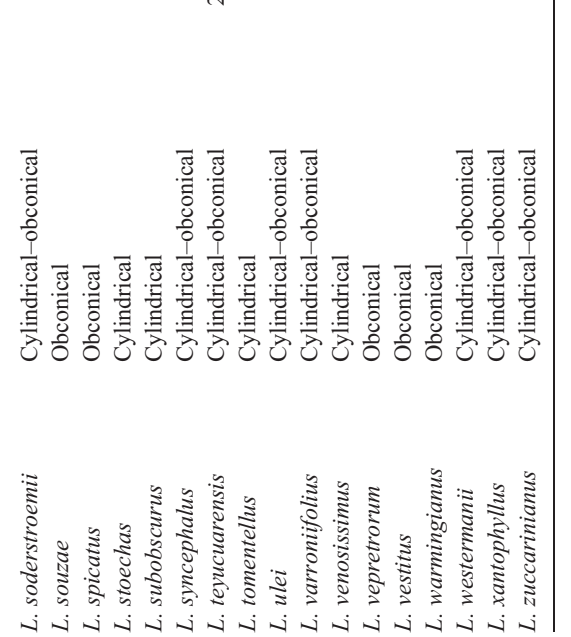

\section{Glabrous cypselae}

Fruit surface is glabrous, without any indumentum on the pericarp (Fig. 1A, B). This morphological type was found in eight species of Lessingianthus (Table 1).

\section{Cypselae with twin hairs}

Fruit surface is covered with twin trichomes that consist of two basal cells and two parallel elongated cells, with slightly thickened and lignified walls. The two parallel cells vary in length and are separated at the apex (Figs 1C, 2A-C). Almost all the analysed species have this morphological type (Table 1).

\section{Cypselas with twin hairs and glandular trichomes}

Fruit surface is covered by twin hairs and glandular trichomes located near the carpopodium. Glandular trichomes have a 3-5celled uniseriate stalk and a unicellular head (Figs 1D, E, 2D-F). This morphological type was found in 19 species of the genus (Table 1). Histochemical tests (Lugol's reagent, Sudan IV, Ruthenium red and cresyl blue) on contents of the head cell showed negative results, indicating the absence of starch grains, lipids, pectinaceous materials and mucilages respectively.

\section{Carpopodium}

All the examined species show the carpopodium as a complete ring formed by several rows of quadrate and subquadrate cells with thickened walls (Fig. 1C-D, F, G). The size of the carpopodium varied among the analysed species, with a mean length ranging from 0.025 to $0.55 \mathrm{~mm}$ and a mean width from 0.25 to $0.85 \mathrm{~mm}$. Only L. grandiflorus showed carpopodium as a very small ring with a few rows of cells of $0.02-0.03 \mathrm{~mm}$ in length and $0.25-0.35 \mathrm{~mm}$ in diameter (Table 1). Lessingianthus compactiflorus had a highly developed ring of $0.4-0.6 \mathrm{~mm}$ in length and $0.55-0.65 \mathrm{~mm}$ in diameter.

\section{Crystals in the pericarp}

Crystals can be prismatic and styloids in the analysed species (Table 1). Prismatic crystals in the fruit wall (Table 1) show different shape, size and density. The shape of these prismatic crystals can be rectangular (Fig. 3A-D) or hexagonal (Fig. 3E, F) in surface view. Considering the size, rectangular crystals are classified as short $(13.56 \mu \mathrm{m} \pm 0.23$ in length $\times 11.60 \mu \mathrm{m} \pm 1.23$ in width) and long $(23.50 \mu \mathrm{m} \pm 2.34$ in length $\times 8.32 \mu \mathrm{m} \pm 1.98$ in width). Most of species show both types of rectangular crystals (Fig. 3C). Hexagonal prismatic crystals $(23.8 \mu \mathrm{m} \pm 2.45 \times 8.00$ $\mu \mathrm{m} \pm 1.56)$ are less common and always were observed together with rectangular crystals (Fig. $3 \mathrm{G}$, Table 1). Lessingianthus argyrophyllus and L. grearii also have styloid crystals (Fig. $3 \mathrm{H}, \mathrm{I}$ ) that are elongated and have acute apices.

Crystals were dissolved with 2\% hydrochloric acid (without producing bubbles), suggesting that they are composed of calcium oxalate $(\mathrm{CaOx})$.

Idioblasts

Almost all the species showed idioblasts clearly distinguishable on the fruit wall, which are ellipsoidal or rounded cells with very dense cytoplasm, evident nucleus, and remarkably thickened and lignified walls (Fig. 4A, B). Only L. durus and L. soderstroemii lack these cells (Table 1). 
Table 2. List of characters and their coding states

\begin{tabular}{ll}
\hline Character number & Fruit character \\
\hline 1 & Fruit shape: cylindrical (1), cylindircal-obconical (2), obconical (3) \\
2 & Fruit types: glabrous cypselae (1), cypselae with twin hairs (2), cypselas with twin hairs and glandular trichomes (3) \\
3 & Idioblasts: absent (0), present (1) \\
4 & Crystals: rectangular prismatic (1), rectangular and hexagonal prismatic (2), hexagonal prismatic and styloid (3) \\
\hline
\end{tabular}
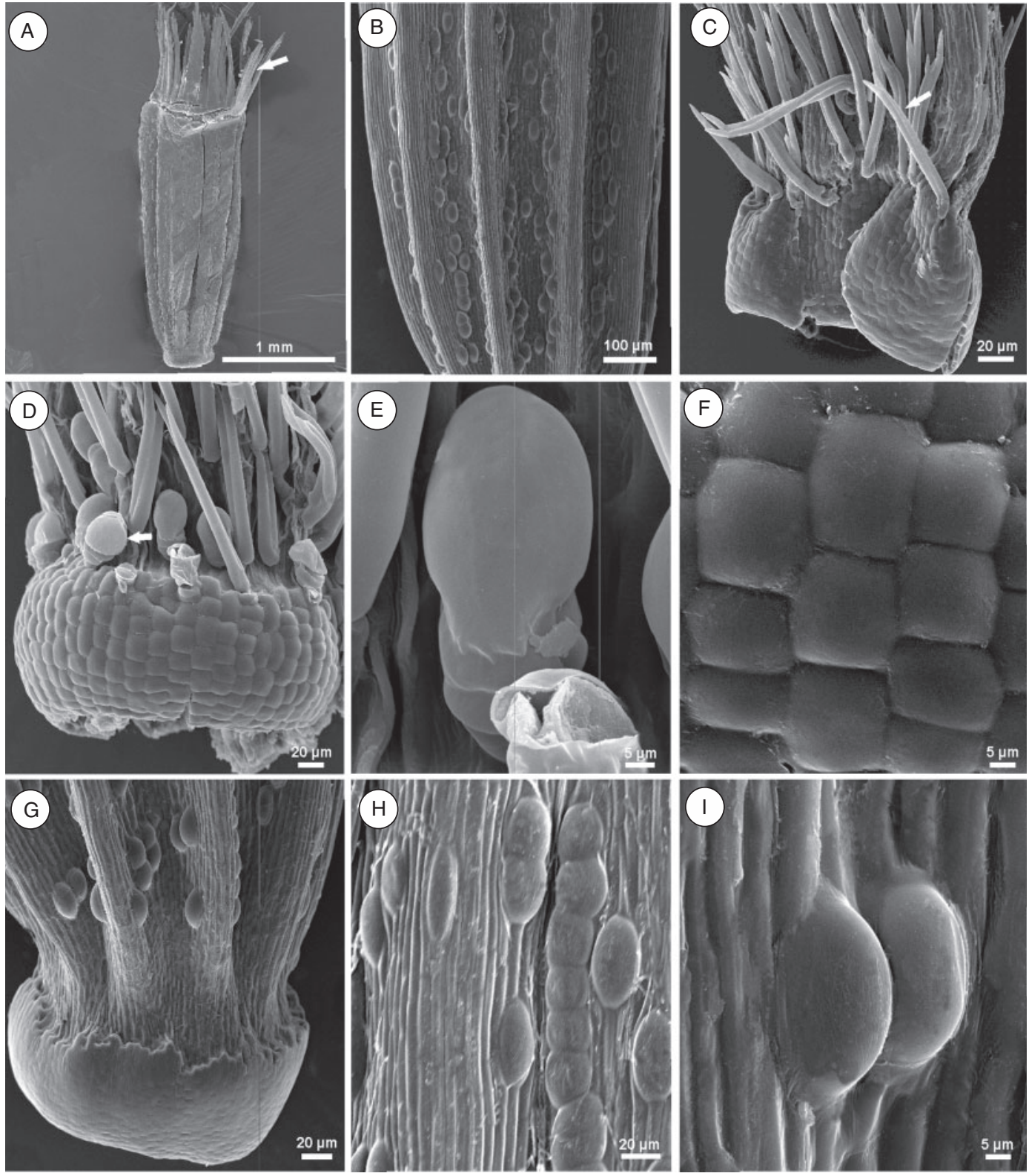

Fig. 1. Cypsela microcharacters of Lessingianthus (scanning electron micrographs): A, B. Glabrous cypsela of L. varroniifolius. A. Glabrous fruit with the external series of pappus (arrow). B. Fruit detail, showing the idioblasts and ribs. C. Detail of carpopodium, showing twin hairs (arrow) of L. bardanoides. D-F. Cypsela of L. ulei. D. Detail of fruit base, showing twin hairs and glandular (arrow) trichomes. E. glandular trichome. F. Detail of carpopodium, showing subquadrate cells. G, H. Glabrous cypsela of $L$. coriarius. G. Cypsela base showing carpopodium and idioblasts. H. Idioblasts scattered and longitudinally arranged along the sides of the ribs, forming groups of up to nine idioblasts. I. Idioblasts of $L$. varroniifolius. 

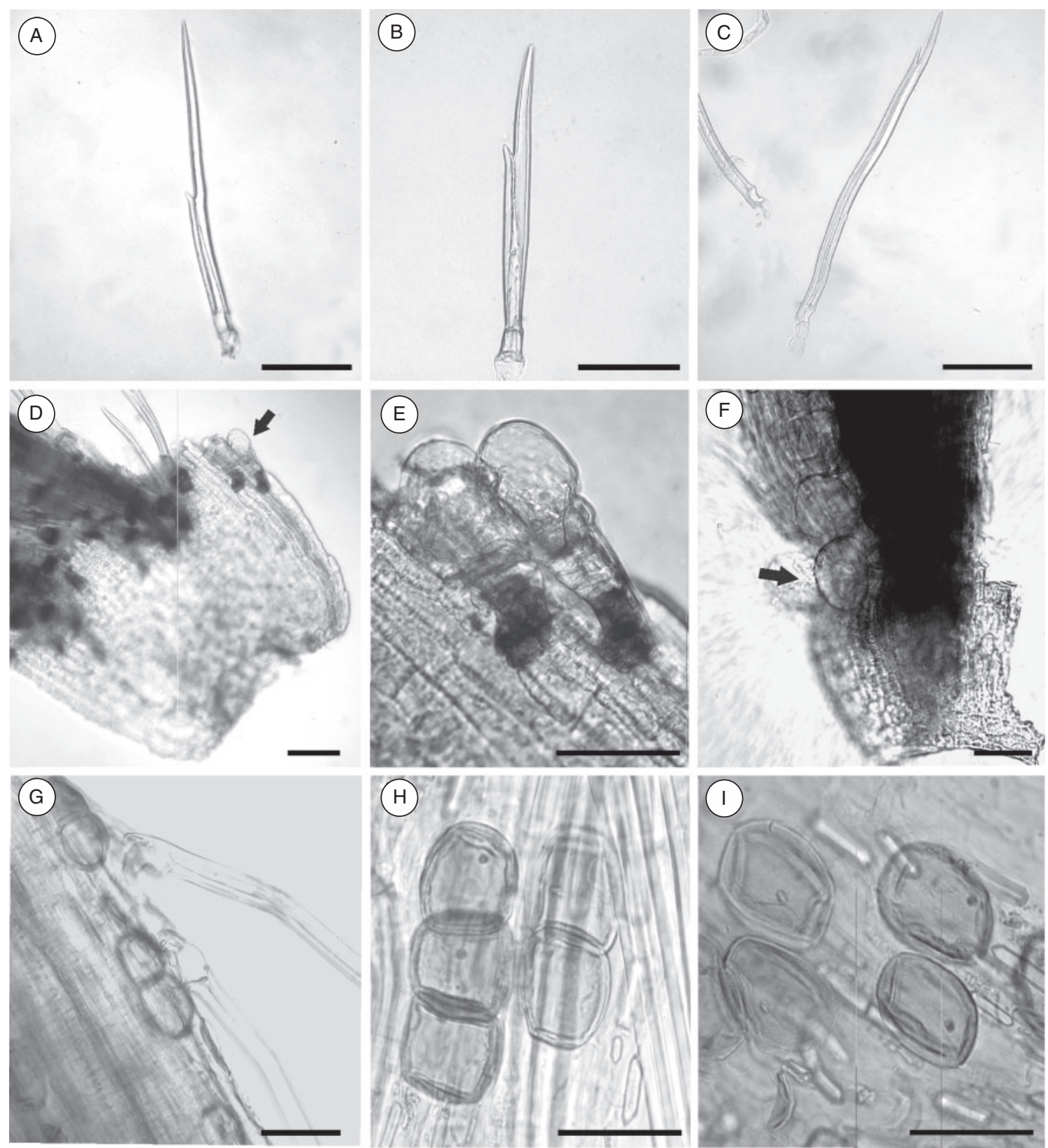

Fig. 2. Cypsela microcharacters of Lessingianthus (light micrographs). A, B. Twin hairs of L. bardanoides. C. Twin hairs of L. argyrophyllus. D, E. Cypsela of L. macrocephalus. D. Detail of the fruit, showing glandular trichomes (arrow) on the carpopodium apex. E. Glandular trichomes on the fruit. F. Fruit detail of L. brevifolius, showing glandular trichomes (arrow) on the carpopodium apex. G. Detail of fruit of L. grearii, showing twin hairs and idioblasts. H. Idioblasts (in groups of two and three) of L. laniferus. I. Solitary idioblasts of L. ulei. Scale bars: $50 \mu \mathrm{m}$ (A-C, E, H, I), $100 \mu \mathrm{m}$ (D, F, G).

Idioblasts are larger than the cells of the uniseriate epidermis, emerging clearly from the fruit wall (Figs 1H, I, 2G-I). In some species (such as L. myrsinites), they can be distinguished under stereomicroscope. They are scattered (Fig. 2I) or longitudinally arranged along the sides of the ribs, forming groups of up to nine idioblasts in L. coriarius (Fig. 1H).

The contents of the idioblasts were submitted to histochemical tests with Lugol's reagent, Sudan IV, Ruthenium red and cresyl blue with negative results, indicating the absence of starch grains, lipids, pectinaceous materials and mucilages respectively.

\section{Statistical analysis}

Principal coordinate analysis ( $\mathrm{PCoA})$ of the cypsela characters showed that the first two principal coordinates represent only $45.6 \%$ of the total variation (see Fig. 5 for a bidimensional 

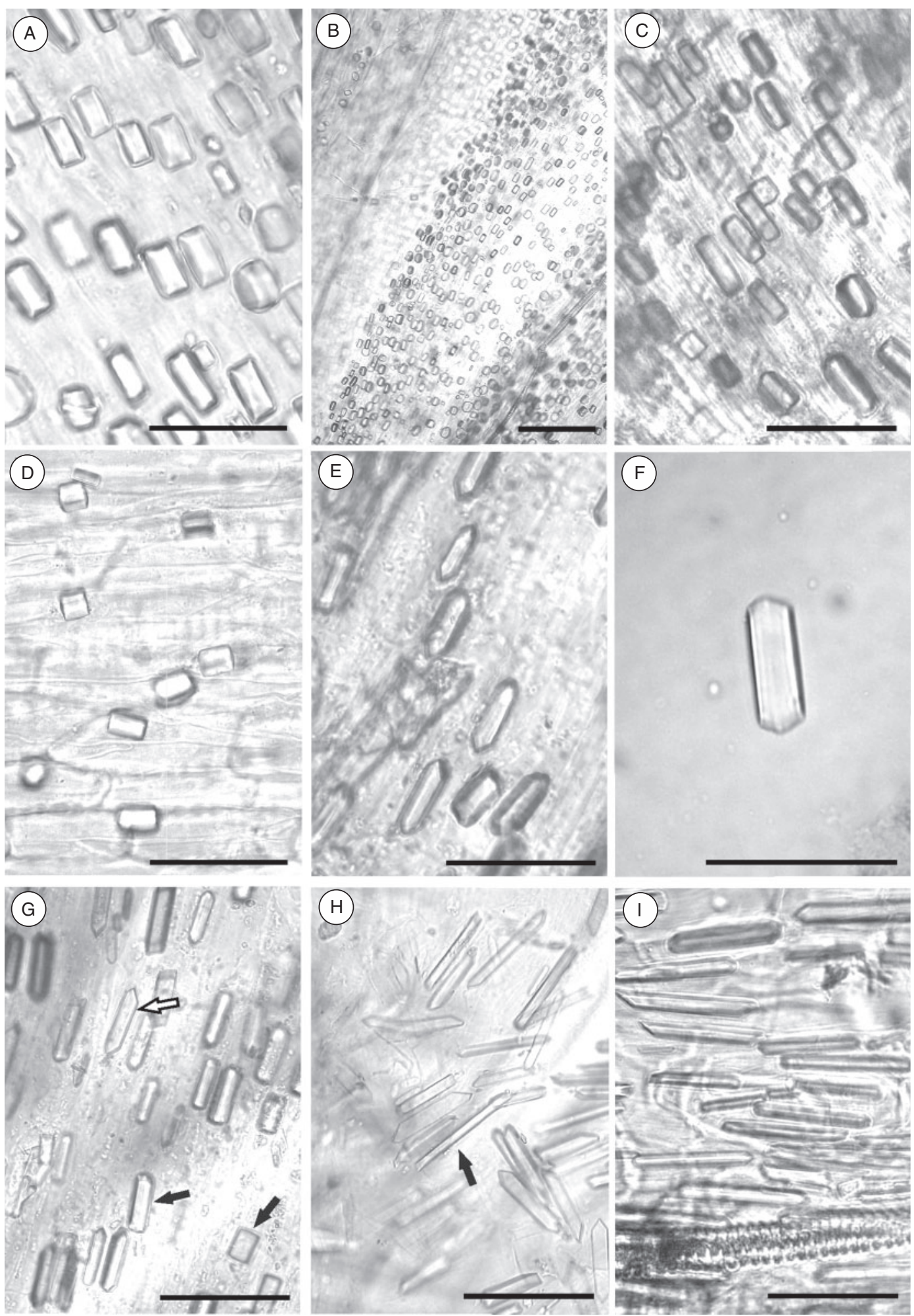

Fig. 3. Crystals of fruit wall of Lessingianthus (light micrographs). A. Rectangular prismatic crystals of L. durus. B. Detail of fruit, showing rectangular prismatic crystals of L. laniferus. C. Rectangular prismatic crystals (short and long) of L. glabratus. D. Short rectangular prismatic crystals of $L$. syncephalus. E, F. Hexagonal prismatic crystals of L. exiguus. G. Hexagonal (empty arrow) and rectangular prismatic (filled arrows) crystals of $L$. plantaginodes. H. Styloid crystals (arrow) of L. argyrophyllus. I. Styloid crystals of L. grearii. Scale bars: $50 \mu \mathrm{m}$ (A, C, D-I), $100 \mu \mathrm{m}$ (B). 

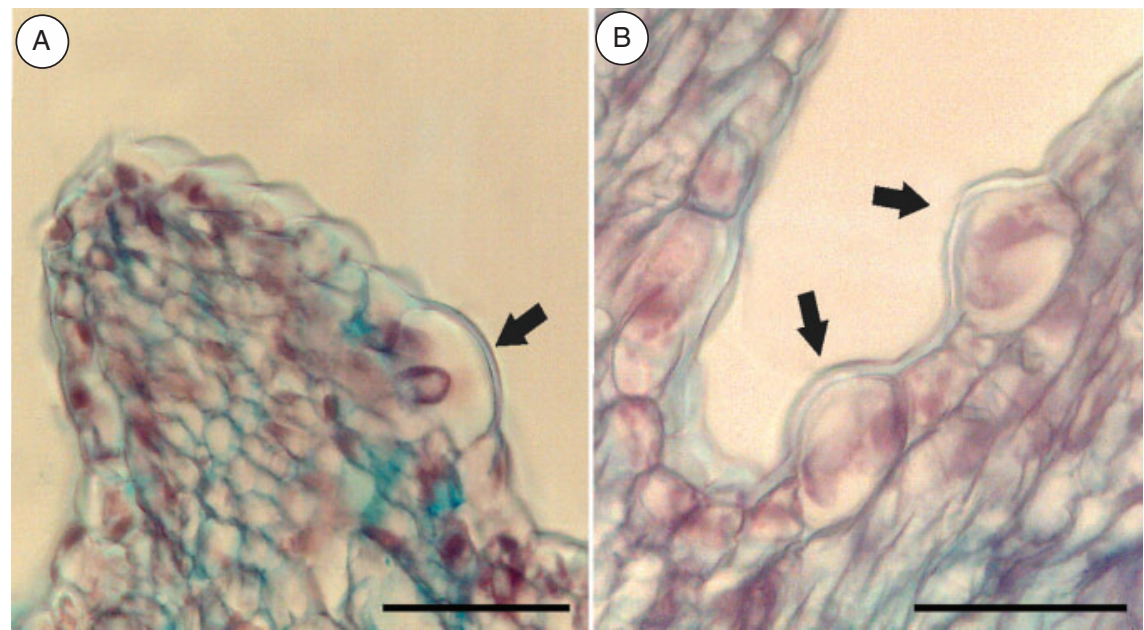

Fig. 4. Transversal sections of fruits (light micrographs). A. Detail of the rib, showing idioblast (arrow) in the epidermis of L. rubricaulis. B. Detail of the idioblasts (arrows) in the epidermis of L. saltensis. Scale bar: $50 \mu \mathrm{m}$.

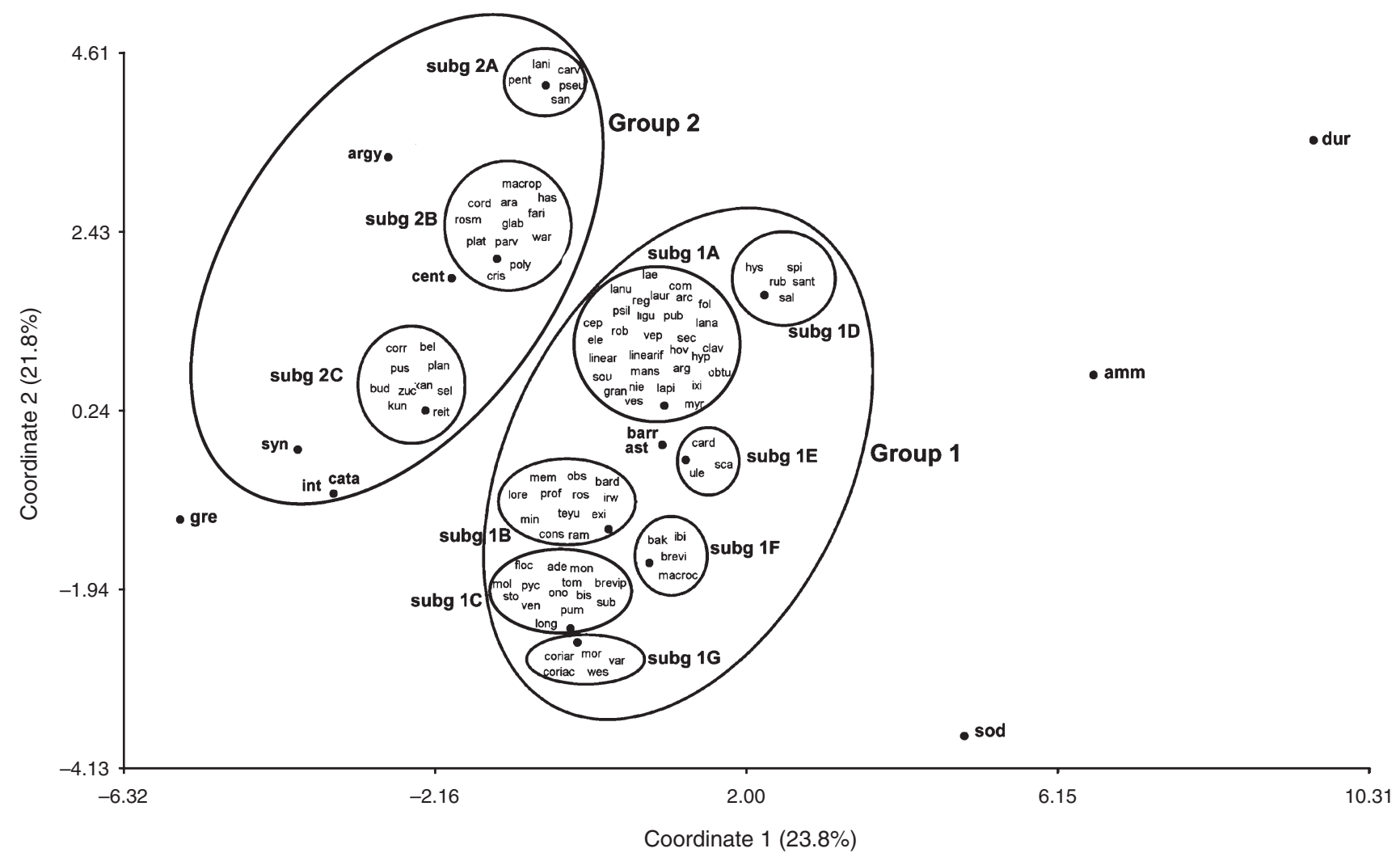

Fig. 5. Graph of the first two principal coordinates of Lessingianthus species on the basis of cypsela characters. Circles show the grouped species by fruit characters and several subgroups (Subgroups 1A-G, 2A-C) are distinguished within. Subgroups include species with the same coordinates (see text). Codes identifying species are in Table 1.

projection of the axes). However, two distinct groups were differentiated. The large Group 1 includes 76 species $(67.85 \%)$, which have rectangular prismatic crystals and idioblasts. Several subgroups containing species with the same distribution (same coordinates) were distinguished within. The same coordinates for species indicate that they share the same micromorphological characteristics. All taxa of the Subgroups 1A (with 31 species), $1 \mathrm{~B}$ (with 12 species) and $1 \mathrm{C}$ (with 14 species) also have cypselae 
with twin hairs but differ in the shape of the fruit. Subgroup 1A has obconical cypselae, whereas Subgroup 1B has cylindical-obconical fruits and Subgroup 1C has cylindrical cypselae. Subgroups 1D ( 5 species), 1E (3 species) and IF (4 species) show cypselae with twin hairs and glandular trichomes and also differ in fruit shape, as follows: obconical (Subgroup ID), cylindrical-obconical (Subgroup IE) and cylindrical (Subgroup IF). The only species with glabrous cylindrical cypselae were grouped in Subgroup IG ( 5 species). Two species (L. barrosoanus and L. asteriflorus) were separated from these subgroups because they had a combination of characters, such as obconical and glabrous fruits.

Group 2 is smaller (with 32 species) than Group 1 and it includes taxa with cypselae with idioblasts and rectangular and hexagonal prismatic crystals. This group also has several subgroups within it; Subgroups 2A (12 species) and 2B (10 species) both have cypselae with twin hairs, but fruits are obconical in 2A and cylindrical-obconical in 2B. Subgroup $2 \mathrm{C}$, with five species, has obconical cypselae with twin hairs and also glandular trichomes. Several taxa have a combination of characters, which does not correspond to the characteristics of the subgroups above. For example, L. centauropsideus shares some characteristic with Subgroup 2B but it has fruits with twin hairs and glandular trichomes. Lessingianthus cataractarum and L. intermedius were separated from the rest of the species because they had cylindrical cypselae.

Lessingianthus syncephalus and L. argyrophyllus were also isolated by having hexagonal prismatic and styloid crystals.

Lessingianthus grearii was separated (on the negative extreme of coordinate 1) from most of species, because it has cylindrical fruits with crystals hexagonal in shape, prismatic and styloids.

Three species were isolated from the main groups (on the positive extreme of coordinate 1) by lacking idioblasts. Lessingianthus durus and L. ammophyllus have obconical fruits with rectangular prismatic crystals but differed in the trichome type on fruits, twin hairs and glandular trichomes in the former and only twin hairs in the latter. In contrast, Lessingianthus soderstroemii has cylindical-obconical fruits with twin hairs and rectangular prismatic crystals.

\section{Discussion}

Several studies have emphasised the importance of cypsela features for systematic investigation in Asteraceae, because they are useful to clarify the delimitation and establish the similarity of taxa in the family (Grau 1977; Robinson and King 1977; Anderberg 1989; Bremer 1994). Cypsela features, including the presence and number of the ribs, crystals in epidermal cells, carpopodium structure, pappus type and trichomes, are used in these classifications because they are stable and genetically controlled (Ciccarelli et al. 2007). In the present paper, we studied 112 species of Lessingianthus to describe and explore whether cypsela features have diagnostic value for taxonomical purposes.

Lessingianthus species show similar characteristics in general morphology of cypselae to those of other genera of Vernonieae (Robinson 1999; Funk et al. 2009). For example, twin hairs on fruit of Lessingianthus were also observed in all Vernonieae, being considered the trichome type that characterises Asteraceae cypselae. Twin hairs, also called double hairs and
'Zwillingshaare' (Kraus 1866), have been extensively studied in the family. Their morphology shows great variation in size, length, wall thickness, degree of divergence and degree of development of the cells and the basal cells (Freire and Katinas 1995; Sancho and Katinas 2002, Ike and Nordenstam 2012). In Lessingianthus, the morphology of twin hairs varies in length and the degree of divergence of parallel cells; however, the overall morphology fits the description proposed by Cabrera (1944) for Vernonia twin hairs. Twin hairs have also been reported in corollas of some species of Asteraceae, such as Encelia Adans. (Heliantheae; Carpenter 1999) and in several genera of Mutisieae (Sancho and Katinas 2002). However, this trichome type was not observed in corollas of Lessingianthus (Angulo and Dematteis 2014) and is restricted only to the fruits.

The genus was found to have three fruit types on the basis of the presence or absence of trichomes, and the trichome type, with the cypselae with twin hairs being the most common type. Glabrous fruits were observed in eight species, whereas the presence of glandular trichomes, along with non-glandular trichomes, was found in 19 species. In Asteraceae, glandular trichomes of the fruit are usually formed by a stalk and a head of one or many cells (Narayana 1979). Glandular trichomes of Lessingianthus share this general structure with a 3-5-celled uniseriate stalk and a unicellular head. A biseriate 10-celled glandular trichome is considered the most common type in Asteraceae and occurs in the tribes Anthemideae (Werker et al. 1994), Astereae (Castro et al. 1997), Eupatorieae (Castro et al. 1997), Heliantheae (Castro et al. 1997), Inuleae (Werker and Fahn 1981), Mutisieae (Castro et al. 1997) and Vernonieae (Faust and Jones 1973; Narayana 1979; Castro et al. 1997). However, this glandular trichome type was not found in Lessingianthus fruits. The structure of glandular trichomes here described agrees with one type (designated as Type III) on corollas of some species of the genus (Angulo and Dematteis 2014). The secretion of lipids by the trichomes of corollas was observed via histochemical tests (Angulo and Dematteis 2014). However, our findings indicated that glandular trichomes of cypselae do not secrete lipids, nor starch, mucilage or pectinaceous materials. In general, the secretions may have many functions, such as attracting pollinating insects to flowers, and will protect the plant and its reproductive organs against pathogens and herbivores (Ciccarelli et al.2007). Therefore, a detailed study of secretory material, with observations of plants in their natural habitat and chemical analysis, can provide a sound basis for speculation about the true function of these fruit trichomes.

The carpopodium may show taxonomically useful variation in size and shape of cells and thickness of cell walls (King and Robinson 1970). However, in Lessingianthus, carpopodia show a comparative uniformity; all the species have this structure as a complete ring without interruptions, although differences in size (length and width) of this ring were observed. Our results agree with the annular carpopodium cited for some species of Vernonia (Haque and Godward 1984), and other genera of Vernonieae (Funk et al. 2009). Within the tribe, only the genus Camchaya Gagnep. has no evident carpopodium (Funk et al. 2009). In other tribes, the carpopodium exhibits greater variability, for example in Wedelia Jacq. (Heliantheae), the shape may change as the fruit matures, and in Ayapaninae (Eupatorieae), the basal row of cells is greatly enlarged (Funk et al. 2009). Several functions have 
been assigned to the carpopodium and all of them are related to seed dispersal. Haque and Godward (1984) suggested that the thickened cells provide a rigid structure which, on drying, will not contract, resulting in tension to the thin-walled cells of the abscission layer, making abscission easier. The function of the carpopodium in Lessingianthus is still unknown, but we consider that its presence is also related to seed dispersal.

The presence of $\mathrm{CaOx}$ crystals in the cypsela wall was observed in all Lessingianthus species. These crystals are common for most vegetative and reproductive organs in plants and are widely distributed in over 215 plant families (Franceschi and Horner 1980; Molano-Flores 2001). However, there are only a few studies related to their presence in Asteraceae (Dormer 1961; Horner 1977; Meric 2008; Meric and Dane 2004). In the present study, prismatic (rectangular and hexagonal) and styloid crystals were observed in Lessingianthus species, with the prismatic shape being the most frequent. Robinson (1988a) established that the genus is characterised by quadrate crystals (the correct term would be cubic because it is a tridimensional structure), whereas Lepidaploa and Chrysolaena have elongated crystals (the correct term would be prismatic). Therefore, the crystal shape is one of the diagnostic features that distinguishes Lessingianthus from those related genera (Robinson 1988a, $1988 b)$. However, we observed a wide variation in the shape and size of the crystals within the genus. Prismatic crystals were the most common, mainly the rectangular crystals, whereas hexagonal shapes were observed in a few species. Only two species had styloid crystals. Therefore, the crystal shape of cypselae is not a good diagnostic character for Lessingianthus because it is very variable and overlapping in most Vernonieae genera.

The mechanisms controlling the morphology of crystals are unknown (Nakata 2003). The diversity of crystal shapes, as well as their prevalence and spatial distribution, has led to several hypotheses about their functions in plants. Some of the proposed functions include roles in ion balance, plant defence, detoxification and tissue support (Franceschi and Horner 1980).

The presence of crystals in both vegetative and reproductive organs was observed in various taxa of Asteraceae (Dormer 1961; Meric and Dane 2004; Meric 2008). It is probable that other reproductive (anthers, petals) and vegetative (leaves, stems, and roots) structures also have crystals in Lessingianthus. Therefore, further studies that include other reproductive and vegetative organs are necessary in the genus, so as to determine their presence and, consequently, their morphology and distribution.

There are studies showing that the process of $\mathrm{CaOx}$ crystal formation may occur in specialised cells, called crystal idioblasts (Mazen et al. 2004). Although the fruit wall of Vernonieae often has idioblasts, there are no studies linking these cells with production of crystals. Almost all of Lessingianthus species showed idioblasts in the cypsela wall, which were clearly distinguishable from trichomes and epidermal cells. Lessingianthus durus and L. soderstroemii had cypselae without idioblasts; however, both species have crystals. Therefore, the observed idioblasts would not be involved in crystal formation. Also, histochemical tests performed here showed that idioblasts do not contain starch grains, lipids, pectinaceous materials or mucilage.

These cells differ from the surrounding tissue cells by their shape, size and wall structure. Hind (1993) described such cells as glands; however, our results indicated that these cells are certainly idioblasts as suggested by Robinson (1999). Such cells differ from the structure of glandular trichomes (uniseriate stalk and unicellular head) observed in Lessingianthus fruits. Their presence or absence has been used as a taxonomic feature for Vernonieae (Isawumi et al. 1996; Robinson 2009). Almost all species of Lessingianthus have idioblasts (only two species do not have these cells); therefore, they are a good taxonomic marker at an infrageneric level.

\section{Taxonomy}

Our findings suggested that cypsela features are useful in distinguishing species of Lessingianthus. The statistical analysis showed that presence or absence of idioblasts and crystal types are the most influential variables. These variables, along with the shape and fruit type, allow differentiation among related species. In the genus, there are several complexes of closely related species that are morphologically similar, but with different ploidy levels. The search for additional diagnostic characters to distinguish the species within these groups is necessary, and cypsela characters analysed here contributed to their differentiation. For example, the L. saltensis complex is one of these groups that includes three species (L. saltensis, L. coriarius and L. membranifolius), which can be distinguished from each other by morphological features, such as texture and shape of leaves, phyllary apex, chromosome number, as well as by some micromorphological features such as corolla pubescence (Angulo and Dematteis 2012a, 2014). Cypselae were also different in L. coriarius where the fruits are glabrous and cylindrial-obconical, whereas L. saltensis had obconical fruit with twin hairs and glandular trichomes, and L. membranifolius had fruit with only twin hairs. Therefore, the cypsela characters are a useful tool to characterise and distinguish species, and their taxonomic value increases when they are considered together with other morphological characters.

As with some other micromorphological characters of Vernonieae, fruit features of Lessingianthus are shared with related genera, namely, Chrysolaena and Lepidaploa, which hinders their use as good taxonomic markers at a generic level. For example, the absence of glandular trichomes on fruits was previously noted as one of the features that distinguish Lessingianthus from Chrysolaena and Lepidaploa (Robinson 1988 a). However, our results indicated that some species of Lessingianthus have glandular trichomes; therefore, this character is shared with these related genera. Crystal shape was another characteristic that distinguished Lessingianthus (quadrate or subquadrate; designed here as 'cubic or subcubic') from Lepidaploa and Chrysolaena (elongate, designed here as 'prismatic'; Robinson 1999). However, our results showed a wide variation in crystals, indicating that this character is also not useful for generic segregation. Idioblasts are present in Lessingianthus as well as in Lepidaploa and Chrysolaena (Robinson 1999), so the presence of these cells is shared by the three genera also. Several studies have shown that micromorphological characters are valuable within the genera of Vernonieae and, when combined with other characters (pollen morphology, chromosome number and inflorescence type), they delimit subtribes, genera and species within geographically defined regions (Robinson 1999; Funk et al. 2009). When 
Robinson (1988a) segregated Lessingianthus, he also used a combination of macro- and micromorphological characters. The cypsela features here analysed may not be good taxonomic markers for the genus; however, they are useful at a species-level classification.

\section{Acknowledgements}

We appreciate support of this work by grants from the Consejo Nacional de Investigaciones Científicas y Tecnológicas (CONICET), the Secretaría General de Ciencia y Técnica de la Universidad Nacional del Nordeste (SGCyT-UNNE), and the Myndel Botanica Foundation.

\section{References}

Abid R, Alam J (2011) Taxonomic significance of cypsela morphology for the tribe Mutisieae (S.L.) (Asteraceae) from Pakistan. Pakistan Journal of Botany 43, 821-826.

Abid R, Ali N (2010) Cypsela morphology and its taxonomic significance for the tribe Senecioneae (Asteraceae) from Pakistan. Pakistan Journal of Botany 42, 117-133.

Abid R, Qaiser M (2009) Taxonomic significance of the cypsela morphology in the tribe Anthemideae (Asteraceae) from Pakistan and Kashmir. Pakistan Journal of Botany 41, 555-579.

Anderberg AA (1989) Phylogeny and reclassification of the tribe Inuleae (Asteraceae). Canadian Journal of Botany 67, 2277-2296. doi: $10.1139 / \mathrm{b} 89-292$

Anderson LE (1954) Hoyer's solution as a rapid mounting medium for bryophytes. The Bryologist 57, 242-247. doi:10.1639/0007-2745(1954)57[242:HSAARP]2.0.CO;2

Angulo MB, Dematteis M (2010) Pollen morphology of the South American genus Lessingianthus (Vernonieae, Asteraceae) and its taxonomic implications. Grana 49, 12-25. doi:10.1080/00173130903435192

Angulo MB, Dematteis M (2012a) Cytotaxonomy of some species of the South American genus Lessingianthus (Asteraceae, Vernonieae). Plant Systematics and Evolution 298, 277-285. doi:10.1007/s00606-011-0542-z

Angulo MB, Dematteis M (2012b) Taxonomy of the Lessingianthus saltensis (Vernonieae, Asteracae) species complex. Annales Botanici Fennici 49, 239-247. doi: $10.5735 / 085.049 .0404$

Angulo MB, Dematteis M (2014) Floral microcharacters in the genus Lessingianthus (Vernonieae, Asteraceae) and its taxonomic implications. Plant Systematics and Evolution 300, 1925-1940. doi:10.1007/s00606-014-1019-7

Bremer K (1994) 'Asteraceae: Cladistic and Classification.' (Timber Press: Portland, OR)

Bunwong S, Chantaranothais P, Keeley S (2014) Revisions and key to the Vernonieae (Compositae) of Thailand. PhytoKeys 37, 25-101. doi:10.3897/phytokeys.37.6499

Cabrera AL (1944) Vernonieas Argentinas (Compositae). Darwiniana 6, $265-379$.

Carpenter KJ (1999) Comparative morphology of disk floret trichomes of Encelia (Asteraceae: Heliantheae). PhD thesis, California State Polytechnic University, Pomona.

Castro MM, Castro H, Leitão-Filho F, Monteiro WR (1997) Utilização de estruturas secretoras na identificação dos gêneros de Asteraceae de uma vegetação do cerrado. Revista Brasileira de Botanica. Brazilian Journal of Botany 20, 163-174. doi:10.1590/S0100-84041997000200007

Ciccarelli D, Garbari F, Pagni AM (2007) Glandular hair of the ovary: a helpful character of Asteroidae (Asteraceae) taxonomy? Annales Botanici Fennici 44, 1-7.

Di Rienzo JA, Casanoves F, Balzarini MG, González L, Tablada M, Robledo CW (2013) InfoStat versión 2013. Grupo InfoStat, FCA, Universidad Nacional de Córdoba.
Dormer KJ (1961) The crystals in the ovaries of certain Compositae. Annals of Botany 25, 241-254.

Faust WZ, Jones SB Jr (1973) The systematic value of trichome complements in a North American group of Vernonia (Compositae). Rhodora 75, $517-528$.

Franceschi VR, Horner HT (1980) Calcium oxalate crystals in plants. Botanical Review 46, 361-427. doi:10.1007/BF02860532

Freire SE, Katinas L (1995) Morphology and ontogeny of the cypsela hairs of Nassauviinae (Asteraceae, Mutisieae). In 'Advances in Compositae Systematics'. (Eds DJN Hind, C Jeffrey, GV Pope) pp. 107-143. (Royal Botanic Gardens, Kew: London)

Funk VA, Susanna A, Stuessy T, Robinson H (2009) Classification of Compositae. In 'Systematics, Evolution, and Biogeography of Compositae.' (Eds VA Funk, A Susanna, TF Stuessy, RJ Bayer) pp. 171-189. (International Association of Plant Taxonony: Vienna, Austria)

Gonzalez AM, Cristóbal CL (1997) Anatomía y ontogenia de semillas de Helicteres lhotzkyana (Sterculiaceae). Bonplandia 9, 287-294.

Grau L (1977) Astereae: systematic review. In 'The Biology and Chemistry of the Compositae. Vol. 1'. (Eds VH Heywood, JB Harborne, BL Turner) pp. 539-565. (Academic Press: London)

Haque MZ, Godward MBE (1984) New records of the carpopodium in Compositae and its taxonomic use. Botanical Journal of the Linnean Society 89, 321-340. doi:10.1111/j.1095-8339.1984.tb02564.x

Hind DJN (1993) Notes on the Compositae of Bahia, Brazil. Kew Bulletin 48, 245-277. doi:10.2307/4117932

Horner HT (1977) A comparative light and electron microscopic study of microsporogenesis in male-fertile and cytoplasmic male-sterile sunflower (Helianthus annuus). American Journal of Botany 64, 745-759. doi: $10.2307 / 2441727$

Ike S, Nordenstam B (2012) Diversity of trichomes from mature cypselar surface of some taxa from the basal tribes of Compositae. Compositae Newsletter 50, 78-124.

Isawumi MA, El-Ghazaly G, Nordenstam B (1996) Pollen morphology, floral microcharacters and taxonomy of the genus Baccharoides Moench (Vernonieae: Asteraceae). Grana 35, 205-230. doi:10.1080/00173139609430008

Johansen DA (1940) 'Plant Microtechnique.' (McGraw-Hill Book Co.: New York)

Keeley SC, Forsman ZH, Chan R (2007) A phylogeny of the 'evil tribe' (Vernonieae: Compositae) reveals $\mathrm{Old} / \mathrm{New}$ World long distance dispersal: support from separate and combined congruent datasets (trnL-F, ndhF, ITS). Molecular Phylogenetics and Evolution 44, 89-103. doi:10.1016/j.ympev.2006.12.024

King RM, Robinson H (1970) The new synantherology. Taxon 19, 6-11. doi: $10.2307 / 1217907$

Kraus G (1866) Über die Bau trockner Pericarpien. Jahrbücher für Wissennschaftliche Botanik 5, 93-126.

Lander NS, Hurter PJH (2013) Pleurocarpaea gracilis (Asteraceae: Vernonieae), a new species from the Pilbara region of Western Australia. Nuytsia 23, 109-115.

Luque R, Sousa HC, Kraus JE (1996) Métodos de coloração de Roeser (1972)modificado- E Kropp (1972), visando a substituição do Azul de Astra por Azul de Alcião8GS ou 8GX. Acta Botanica Brasílica 10, 199-212.

Martins MAG, Oliveira DMT (2007) Ontogênese do fruto de Vernonia brevifolia e $V$. herbacea. Revista Brasileira de Botanica. Brazilian Journal of Botany 30, 101-112. doi:10.1590/S0100-84042007000100010

Marzinek J, Cavalari de-Paula O, Trombert Oliveira DM (2008) Cypsela or achene? Refining terminology by considering anatomical and historical factors. Revista Brasileira de Botanica. Brazilian Journal of Botany 31, 549-553. doi:10.1590/S0100-84042008000300018

Mazen AMA, Zhang D, Franceschi VR (2004) Calcium oxalate formation in Lemna minor: physiological and ultrastructural aspects of high capacity 
calcium sequestration. New Phytologist 161, 435-448. doi:10.1111/j.1469-8137.2004.00923.x

Meric C (2008) Calcium oxalate crystals in Conyza canadensis (L.) Cronq. and Conyza bonariensis (L.) Cronq. (Asteraceae: Astereae). Acta Biologica Szegediensis 52, 295-299.

Meric C, Dane F (2004) Calcium oxalate crystals in floral organs of Helianthus annuus L. and H. tuberosus L. (Asteraceae). Acta Biologica Szegediensis 48, 19-23.

Metcalfe CR, Chalk L (1979) 'Anatomy of the Dicotyledons. Vol. I.' (Clarendon Press: Oxford, UK)

Molano-Flores B (2001) Herbivory and calcium concentrations affect calcium oxalate crystal formation in leaves of Sida (Malvaceae). Annals of Botany 88, 387-391. doi:10.1006/anbo.2001.1492

Nakata PA (2003) Advances in our understanding of calcium oxalate crystal formation and function in plants. Plant Science 164, 901-909. doi:10.1016/S0168-9452(03)00120-1

Narayana BM (1979) Taxonomic value of trichomes in Vernonia Schreb. (Asteraceae). Proceedings of the Indian Academy of Sciences, $\mathbf{8 8}$ (Section A), 347-357.

Robinson H (1988a) Studies in the Lepidaploa complex (Vernonieae: Asteraceae). IV. The new genus Lessingianthus. Proceedings of the Biological Society of Washington 100, 929-951.

Robinson H (1988b) Studies in the Lepidaploa complex (Vernonieae: Asteraceae). V. The new genus Chrysolaena. Proceedings of the Biological Society of Washington 101, 952-958.

Robinson H (1999) Generic and subtribal classification of American Vernonieae. Smithsonian Contributions to Botany 89, 1-116. doi:10.5479/si.0081024X.89

Robinson H (2007) Tribe Vernonieae. In 'The Families and Genera of Vascular Plants. Vol. 8'. (Eds J Kadereit, C Jeffrey) pp. 165-192. (Springer: Berlin)

Robinson H (2009) An introduction to micro-characters of Compositae. In 'Systematics, Evolution and Biogeography of Compositae'. (Eds VA
Funk, A Susanna, TF Stuessy, RJ Bayer) pp. 89-100. (International Association for Plant Taxonomy: Vienna, Austria)

Robinson H, King RM (1977) Eupatorieae-systematic review. In 'The Biology and Chemistry of the Compositae'. (Eds VH Heywood, JB Harborne, BL Turner) vol. 1, pp. 437-485. (Academic Press: New York)

Roque N, Funk V (2013) Morphological characters add support for some members of the basal grade of Asteraceae. Botanical Journal of the Linnean Society 171, 568-586. doi:10.1111/boj.12000

Roque N, Keil DJ, Susanna A (2009) Illustrated glossary of Compositae. In 'Systematics, Evolution, and Biogeography of Compositae'. (Eds VA Funk, A Susanna, TF Stuessy, RJ Bayer) pp. 781-806. (International Association of Plant Taxonony: Vienna, Austria)

Sancho G, Katinas L (2002) Are the trichomes in corollas of Mutisieae (Asteraceae) really twin hairs? Botanical Journal of the Linnean Society 140, 427-433. doi:10.1046/j.1095-8339.2002.00113.x

Spjut RW (1994) A systematic treatment of fruit types. Memoirs of the New York Botanical Garden 70, 1-182.

Werker E, Fahn A (1981) Secretory hairs of Inula viscose (L.) Ait. Development ultrastructure and secretion. Botanical Gazette 142, 461-476. doi:10.1086/337247

Werker E, Putievsky E, Ravid U, Dudai N, Katzir I (1994) Glandular hairs, secretory cavities, and the essential oil in leaves of tarragon (Artemisia dracunculus L.). Journal of Herbs, Spices \& Medicinal Plants 2, 19-32. doi:10.1300/J044v02n03_04

Zarlavsky GE (2014) 'Histología Vegetal: técnicas simples y complejas.' (Sociedad Argentina de Botánica: Buenos Aires)

Zhang JW, Boufford DE, Sun H (2013) Systematic significance of achene morphology in Soroseris, Syncalathium and Parasyncalathium (Asteraceae: Cichorieae). Botanical Journal of the Linnean Society 173, 476-486. doi:10.1111/boj.12046 
Appendix 1. Specimens analysed

Lessingianthus adenophyllus (Mart. ex DC.) H.Rob.

BRAZIL, Minas Gerais: Menezes et al. 11878 (CTES).

L. ammophyllus (Gardner) H. Rob.

BRAZIL, Minas Gerais: Smith et al. 103262 (CTES).

L. arachniolepis (Ekman \& Dusen) H.Rob.

BRAZIL, Paraná: Barbosa and Costa 1025 (CTES).

L. arctatus Dematt.

BRAZIL, Goiás: Magenta et al. 266 (CTES).

L. argenteus (Less.) H.Rob.

BRAZIL Paraná: Hatschbach 1989 (CTES). PARAGUAY, Amambay: Dematteis et al. 3396 (CTES).

L. argyrophyllus (Less.) H.Rob.

BRAZIL, Brasília: Krapovickas et al. 31158 (CTES). Minas Gerais: Krapovickas et al. 33353 (CTES).

L. asteriflorus (Mart ex DC.) H. Rob.

BRAZIL, Paraná: Silva et al. 6099 (CTES), BOLIVIA, Santa Cruz: Solís Neffa et al. 1351 (CTES).

L. bardanoides (Less.) H.Rob.

BRAZIL, Mato Grosso do Sul: Hatschbach et al. 58736 (CTES). PARAGUAY, Amambay: Dematteis et al. 3393 (CTES).

L. barrosoanus Dematt.

BRAZIL, Bahía: Guédès et al. s.n. (SPF).

L. bakerianus Dematt.

BRAZIL, Minas Gerais: Warming 2867 (CTES).

L. bellulus Dematt.

BRAZIL, Mato grosso do Sul: Hatschbach et al. 58687 (CTES).

L. bishopii (H.Rob.) H.Rob.

BRAZIL, Goiás: Saint Hilaire 487 (P).

L. brevifolius (Less.) H.Rob.

ARGENTINA, Corrientes: Angulo 11 (CTES). BRAZIL, Paraná: Silva et al. 5152 (CTES). PARAGUAY, Alto Paraná: Schinini et al. 28196 (CTES).

URUGUAY, Rivera: Bonifacino and Wilson 2140 (CTES).

L. brevipetiolatus (Sch. Bip. ex Baker) H.Rob.

BRAZIL, Minas Gerais: Roth 1615 (CESJ).

L. buddlejifolius (Mart. ex DC.) H.Rob.

BRAZIL, Goiás: Krapovickas et al. 33270 (CTES).

L. carduoides (Baker) H.Rob.

BRAZIL, Goiás: Gardner 4192 (P).

L. carvalhoi (H.Rob.) H.Rob.

BRAZIL, Bahía: Conceição 785 (ALCB); Harley et al. 50404 (CTES).

L. cataractarum (Hieron.) H.Rob.

ARGENTINA, Misiones: Gatti 28 (CTES). BRAZIL, Paraná: Ribas et al. 6258 (CTES).

L. centauropsideus (Hieron.) Dematt.

ARGENTINA, Salta: Arbo et al. 9107 (CTES).

L. cephalotes (DC) H.Rob.

BRAZIL, Goiás: Glaziou 21577 (G). Minas Gerais: Mello Silva et al. CFCR 5768, SPF 35568 (CTES).

L. clavatus (Gardner) Dematt.

BRAZIL, Minas Gerais: Mexia 5536 (P).

L. compactiflorus (Mart. ex Baker) H.Rob.

BRAZIL, Goiás: Hatschbach 43705 (CTES).

L. constrictus (Matzenb. \& Mafioleti) Dematt.

BRAZIL, Río Grande do Sul: Krapovickas and Cristóbal 44772 (CTES). Irgang 9865 (CTES).

L. cordiger (Mart. ex DC.) H. Rob.

BRAZIL, Minas Gerais: Hatschbach et al. 72053 (MBM, CTES). Semir et al. CFCR 9510, SPF 42759 (CTES).

L. coriaceus (Less.) H.Rob.

BRAZIL, Minas Gerais: Krapovickas et al. 33375 (CTES). BOLIVIA, Santa Cruz: Dematteis et al. 2066 (CTES).

L. coriarius M.B. Angulo

BOLIVIA, Chuquisaca: Beck 6252 (CTES). Santa Cruz: Dematteis et al. 3660 (CTES); Fuentes 2372 (CTES).

L. correntinus (Cabrera \& Cristób.) Dematt.

ARGENTINA, Corrientes: Schinini and Ahumada 13895 (CTES).

L. cristalinae (H.Rob.) H.Rob.

BRAZIL, Goiás: Barroso 522 (UB).

L. durus (Mart. ex DC.) H.Rob.

BOLIVIA, Santa Cruz: Dematteis et al. 2102 (CTES). BRAZIL, Goiás: Hatschbach et al. 70856 (CTES).

L. elegans (Gardner) H.Rob.

BRAZIL, Minas Gerais: Souza et al. 10107 B (CTES).

L. exiguus (Cabrera) H.Rob. 
Appendix 1. (continued)

BRAZIL, Paraná: Krapovickas and Cristobal 40842 (CTES).

L. farinosus (Baker) H.Rob.

BRAZIL, Bahia: Giulietti et al. CFCR 1293 (CTES).

L. floccosus (Gardner) H.Rob.

BRAZIL, Minas Gerais: Gardner $4786(\mathrm{G})$.

L. foliosus Dematt.

BRAZIL, San Pablo: Glaziou 8133 (P).

L. glabratus (Less.) H.Rob.

ARGENTINA, Corrientes: Vanni et al. 1476 (CTES).

L. grandiflorus (Less.) H.Rob.

BRAZIL, Goiás: Hatschbach et al. 70744 (CTES), Paraná: Krapovickas and Cristobal 40756 (CTES). PARAGUAY, Amambay: Dematteis and Schinini 859 (CTES).

L. grearii (H.Rob.) H.Rob,

BRAZIL, Goiás: Paula-Souza et al. 4563 (CTES).

L. hasslerianus (Chodat) Dematt.

PARAGUAY, Itapúa: Montes 7161 (CTES).

L. hoveifolius (Gardn.) H.Rob.

BRAZIL, Goiás: Hatschbach et al. 70576 (CTES).

L. hypochaeris (DC) H.Rob.

BRAZIL, Paraná: Silva and Ribas 3491 (CTES).

L. hystricosus (Cabrera \& Dematt.) Dematt.

PARAGUAY, Amambay: Dematteis et al. 905 (CTES). Cordillera: Schinini 10908 (CTES).

L. ibitipocensis Borges \& Dematt.

BRAZIL, Minas Gerais: Saint Hilaire 200 (P).

L. intermedius (DC.) Dematt.

URUGUAY, Colonia: Solis Neffa et al. 2089 (CTES). Montevideo: Sellow s. n. (BR).

L. irwinii (G.M. Barroso) H.Rob.

BRAZIL, Goia 's: Glaziou s.n. (G).

L. ixiamensis (Rusby) H.Rob.

BOLIVIA, Beni: Krapovickas and Schinini 34882 (CTES). BRAZIL, Mato Grosso: Pedersen 12213 (CTES).

L. kuntzei (Hieron.) Dematt.

BOLIVIA, Santa Cruz: Saravia Toledo 12309 (CTES); Vargas 880 (CTES).

L. laevigatus (Mar. ex DC.) H.Rob.

BOLIVIA, Beni: Solomon 7881 (CTES). BRAZIL, Minas Gerais: Hatschbach et al. 64730 (CTES).

L. lanatus (Cabrera) Dematt.

PARAGUAY, Caaguazú: Schinini et al. 36145 (CTES). Cordillera: Schinini 2211 (CTES).

L. laniferus (Cristobal \& Dematt.) M. B. Angulo

ARGENTINA, Corrientes: Krapovickas et al. $18056 \mathrm{~b}$ (CTES). Misiones: Maruñak 119 (CTES). BRAZIL, Santa Catarina: Ribas and Hatschbach 7513 (CTES).

URUGUAY, Rivera: Dematteis and Schinini 1448 (CTES).

L. lanuginosus Dematt.

BRAZIL, Brasilia: Krapovickas et al. 33175 (CTES). Goiás: Serra dos Pireneus, Hatschbach et al. 70059 (CTES).

L. lapinhensis Dematt.

BRAZIL, Minas Gerais: Pirani et al. 12129 (CTES).

L. laurifolius (H. B. K.) H.Rob.

BOLIVIA, La Paz: Beck 19805 (CTES).

L. liguliifolius (Mart. ex DC.) H.Rob.

BRAZIL, Distrito Federal: Krapovickas and Cristóbal 3190 (CTES). Goiás: Hatschbach and Silva 59996 (CTES).

L. linearifolius (Less.) H.Rob.

BRAZIL, Minas Gerais: Saavedra et al. 270 (CTES). Serra de Ibitipoca: Sucre and Krieger 6850 (CTES).

L. linearis (Spreng.) H.Rob.

BRAZIL, Bahia: Ganev 186 (CTES). Minas Gerais: Vidal I-828 (CTES).

L. longicuspis Dematt.

BOLIVIA, Santa Cruz: Dematteis et al. 2186 (CTES).

L. lorentzii (Hieron.) H.Rob.

ARGENTINA, Corrientes: Carnevalli 4413 (CTES). Entre Rios: Martínez Crovetto 4818 (CTES).

L. macrocephalus (Less.) H.Rob.

BRAZIL, Rio Grande do Sul: Deble et al. s.n. (CTES). URUGUAY, Rivera: Pedersen 11648 (CTES).

L. macrophyllus (Less.) H.Rob.

BRAZIL, Parana: Hatschbach et al. 66520 (CTES)

L. mansoanus (Baker) H.Rob.

BRAZIL, Mato Grosso do Sul: Hatschbach et al. 66643 (CTES). Mato Grosso: Hatschbach et al. 66727 (CTES).

L. membranifolius M.B. Angulo 
Appendix 1. (continued)

BOLIVIA, Santa Cruz: Dematteis et al. 2383 (CTES); Dematteis et al. 2362 (CTES).

L. minimus Dematt.

BRAZIL, Goiás: Hatschbach and Kummrow 37253 (CTES).

L. mollissimus (D. Don ex Hook \& Arn.) H.Rob.

ARGENTINA, Misiones: Krapovickas and Cristóbal 28841 (CTES). BRAZIL, Rio Grande do Sul: Hagelund 7851 (CTES). PARAGUAY, Alto Paraná:

Caballero Marmori s.n. (CTES).

L. monocephalus (Gardner) H Rob.

BRAZIL, Goiás: Pereira-Silva et al. 9935 (CTES), Minas Gerais: Schinini and Barbosa 71330 (CTES).

L. morii (H.Rob.) H.Rob.

BRAZIL, Bahia: Hatschbach et al. 67666 (CTES).

L. myrsinites H.Rob.

BRAZIL, Goiás: Hatschbach et al. 60128 (CTES).

L. niederleinii (Hieron.) H.Rob.

ARGENTINA, Misiones: Montes 192 (CTES). BRAZIL, Mato Groso de Sul: Hatschbach et al. 74473 (CTES). PARAGUAY, Caaguazú: Lopez et al. 196 (CTES).

L. obscurus (Less.) H.Rob.

BRAZIL, Goiás: Gardner $3791(\mathrm{G})$.

L. obtusatus (Less.) H.Rob.

BOLIVIA, Santa Cruz: Killeen et al. 6499 (CTES). BRAZIL, Goiás: Hatschbach et al. 60116 (CTES).

L. onopordioides (Baker) H.Rob.

BRAZIL, Mato Groso do Sul: Souza et al. 16972 (CTES).

L. parvifolius (Chodat) H.Rob.

PARAGUAY, Cordillera: Bordas 1257 (CTES). Paraguari: Mereles et al. 8453 (CTES).

L. pentacontus (DC) H.Rob.

BRAZIL, Minas Gerais: Hatschbach et al. 64852 (CTES); Hatschbach et al. 64644 (CTES).

L. plantaginodes (Kuntze) H.Rob.

ARGENTINA, Corrientes: San Martín. Medina and Salas 378 (CTES). Entre Rios: Krapovickas and Cristobal 46566 (CTES). BRAZIL, Porto Alegre: Bueno 2148 (CTES). URUGUAY, Soriano: Castellanos 17612 (CTES).

L. platyphyllus (Chodat) H.Rob.

BRAZIL, Mato Groso do Sul: Hatschbach et.al. 74558 (CTES). PARAGUAY, Amambay: Dematteis and Schinini 865 (CTES).

L. polyphyllus (Sch. Bip. ex Baker) H.Rob.

ARGENTINA, Misiones: Dematteis 2752 (CTES). BRAZIL, Paraná: Hatschbach 79600 (CTES). PARAGUAY, Amambay: Schinini et al. 36102 (CTES).

L. profusus (Dematt. \& Cabrera) M. B. Angulo

BRAZIL, San Pablo: Panizza SPF 17789 (CTES). PARAGUAY, Amambay: Schinini et al. 30440 (CTES).

L. pseudoincanus (Hieron.) Dematt. \& Angulo

ARGENTINA, Buenos Aires: Mazzucconi 967 (CTES). Corrientes: Angulo 9 (CTES). Salta: Tolaba 2039 (CTES). BRAZIL, Rio Grande do Sul: Rambo 1968 (LP). URUGUAY, Rocha: Rossengurtt 2448 (LP).

L. pseudopiptocarphus (H.Rob.) H.Rob.

BRAZIL, Goiás: Machado Teles et al. 1906 (RB).

L. psilophyllus (Sch. Bip. ex Baker) H.Rob.

BRAZIL, Minas Gerais: Hatschbach et al. 51076 (CTES); Hatschbach et al. 64716 (CTES).

L. pubescens Angulo \& Dematt.

BOLIVIA, Boquerón: Vanni et al. 2418 (CTES). PARAGUAY, Amambay: Dematteis and Schinni 876 (CTES, G).

L. pumilus (Vell.) H.Rob.

BRAZIL, Paraná: Hatschbach 25932 (CTES)

L. pusillus (Dematt.) M.B. Angulo.

ARGENTINA, Chaco: Dematteis 605 (CTES). Corientes: Dematteis et al. 2769 (CTES). Formosa: Morel 5107 (CTES). PARAGUAY, Concepción: Dematteis et al.

3234 (CTES).

L. pycnostachys (DC) H.Rob.

BRAZIL, Minas Gerais: Motta 1243 (CTES); Arbo et al. 4949 (CTES).

L. ramellae (Cabrera) H.Rob.

PARAGUAY, Paraguarí: Hassler 6674 (G).

L. regis (H.Rob.) H.Rob.

BRAZIL, Minas Gerais: Zappi et al. 10301 (CTES)

L. reitzianus (Cabrera) H.Rob.

BRAZIL, Santa Catarina: Silva and Andrade 5462 (CTES). Paraná: Ferrucci et al. 236 (CTES); Hatschbach 39206 (CTES).

L. robustus (Rusby) H.Rob.

BOLIVIA, La Paz: Krapovickas 46754 (CTES). Santa Cruz: Fuentes and Navarro 2183 (CTES). BRAZIL, Mato Grosso: Riedel 1474 (P).

L. roseus (Mart. ex DC.) H.Rob.

BRAZIL, Minas Gerais: Krapovickas and Cristobal 33517 (CTES); Abudd et al. CFSC 10752 (CTES); Damazio 1465 (RB).

L. rosmarinifolius (Less.) H.Rob. 
Appendix 1. (continued)

BRAZIL, Minas Gerais: Arbo et al. 3913 (CTES); Arbo et al. 4170 (CTES).

L. rubricaulis (Humb. \& Bonpl.) H.Rob.

ARGENTINA, Corrientes: Dematteis et al. 2756 (CTES). Misiones: Dematteis and Surenciski 2452 (CTES). BOLIVIA, Santa Cruz: Dematteis et al. 3567 (CTES). BRAZIL, Mato Grosso do Sul: Hatschbach et al. 74696 (CTES). PARAGUAY, Amambay: Dematteis et al. 3375 (CTES).

L. saltensis (Hieron.) H.Rob.

ARGENTINA, Jujuy: Dematteis et al. 2952 (CTES). Salta: Pozner and Belgrano 454 (CTES). BOLIVIA, Chiquitos: Dematteis et al. 2334 (CTES, SI).

L. sancti-pauli (Hieron.) Dematt.

BRAZIL, Paraná: Von Lisingen and Sonehara 115 (CTES).

L. santosii (H.Rob.) H.Rob.

BRAZIL, Bahı 'a: Giulietti 1275 (CTES). Minas Gerais: Arbo et al. 5133 (CTES).

L. scabrifoliatus (Hieron.) H.Rob.

BOLIVIA, Santa Cruz: Seijo 3215 (CTES).

L. secundus (Sch. Bip. ex Baker) H.Rob.

BRAZIL, Goiás: Glaziou 21634 (R).

L. sellowii (Less.) H.Rob.

ARGENTINA, Misiones: Dematteis 588 (CTES). BRAZIL, Rio Grande do Sul: Deble and Oliveira, s.n. (CTES). URUGUAY, Tacuarembó: Dematteis et al. 3760 (CTES)

L. soderstroemii (H.Rob.) H.Rob.

BRAZIL, Minas Gerais: Souza et al. 25168 (ESA); Hatschbach et al. 54521 (CTES); Hatschbach et al. 58357 (CTES).

L. souzae (H.Rob.) H.Rob.

BRAZIL, Goiás: Glaziou 21632 (BR).

L. spicatus (Cabrera) Dematt.

ARGENTINA, Misiones: Schwatz 5491 (CTES); Schulz 185 (CTES).

L. stoechas (Mart. ex DC.) H.Rob.

BRAZIL, Minas Gerais: Hatschbach et al. 72051 (CTES).

L. subobscurus (Malme) H.Rob.

BOLIVIA, Santa Cruz: Seijo and Solis Neffa 3248 (CTES).

L. syncephalus (Sch. Bip.) H.Rob.

BRAZIL, San Pablo: Hohene 2102 (CTES). PARAGUAY, Alto Paraná: Schinini et al. 28185 (CTES).

L. teyucuarensis (Cabrera) Dematt.

ARGENTINA, Misiones: Dematteis et al. 515 (CTES).

L. tomentellus (Mart. ex DC.) H.Rob.

BRAZIL, Minas Gerais: Hatschbach et al. 64579 (CTES).

L. ulei (Hieron.) H.Rob.

BRAZIL, Paraná: Barbosa and Cordeiro 1195 (CTES); Ribas et al. 5060 (CTES).

L. varroniifolius (DC.) H.Rob.

BOLIVIA, Santa Cruz: Dematteis et al. 3860 (CTES); Beck 25852 (CTES).

L. venosissimus (Sch. Bip. Ex Baker)

BRAZIL, Mato Grosso: Hatschbach et al. 66618 (CTES). Rondonia: Krapovickas et al. 40142 (CTES).

L. vepretorum (Mart. ex DC.) H.Rob.

BRAZIL, Minas Gerais: Weddell 1073 (G); Pirani CFSC 12815 (CTES).

L. vestitus (Baker) H.Rob.

BRAZIL, Minas Gerais: Claussen s. n. (P).

L. warmingianus (Baker) H.Rob.

BRAZIL, Minas Gerais: Glaziou 20383 (R); Krapovickas and Cristobal 33496 (CTES); Souza et al. 29576 (CTES).

L. westermanii (Ekman \& Dusén) H.Rob.

BRAZIL, Paraná: Dusén 16400 (G).

L. xanthophyllus (Mart. ex DC.) H.Rob.

BRAZIL, Tocatins: Paula-Souza et al. 4763 (CTES).

L. zuccarinianus (Mart. ex DC.) H.Rob.

BRAZIL, Goiás: Weddell 2060 (P). Mato Grosso: Hatschbach et al. 62350 (CTES). 